\title{
UPAYA MENGHINDARI BULLYING PADA ANAK USIA DINI MELALUI PARENTING
}

\author{
Astri Tirmidziani ${ }^{1}$, Nur Salma Farida ${ }^{2}$, Resti Fauzi Lestari ${ }^{3}$, Rima Trianita ${ }^{4}$, Sopi
}

Khoerunnisa, ${ }^{5}$ Elfan Fanhas Fatwa Khomaeny,

${ }^{1.6}$ Universitas Muhammadiyah Tasikmalaya

tirmidziani@gmail.com ${ }^{1}$, nursalmafarida98@gmail.com ${ }^{2}, \underline{\text { restifauzi70@gmail.com }}{ }^{3}$ rimatrianita98@ gmail.com ${ }^{4}$, sofikhoerunnisa0304@gmail.com, ${ }^{5}$

elfan.fanhas@umtas.ac.id ${ }^{5}$,

\begin{abstract}
ABSTRAK
Di Indonesia sejak tahun 2011 hingga september 2017, Komisi Perlindungan Anak Indonesia (KPAI) menerima 26 ribu kasus anak. Laporan tertinggi yang diterima KPAI adalah anak yang berhadapan dengan hukum termasuk didalamnya adalah kasus Bullying. hal ini tentunya akan memberikan dampak yang buruk terhadap lingkungan. Anak usia dini akan rentan untuk meniru prilaku-prilaku yang dilihat olehnya, termasuk perilaku bullying. Bullying bisa berupa fisik, verbal, dan mental/psikologis, dan dapat mempengaruhi pertumbuhan dan perkembangan anak. Dengan menggunakan pendekatan metode kualitatif yaitu dengan studi literature, penulis menemukan salah satu cara epektif dalam meminimalisir prilaku bullying pada anak usia dini, yaitu dengan cara melaksanakan kegiatan parenting dalam bentuk kunjungan ke rumah anak didik, mengundang orang tuan ke sekolah, dan case conference.
\end{abstract}

Kata Kunci: Menghindari Bullying; Anak Usia Dini; Parenting.

\section{ABSTRACK}

In Indonesia from 2011 to September 2017, the Indonesian Child Protection Commission (KPAI) received 26,000 cases of children. The highest report received by KPAI is the child facing the law including Bullying case. this will certainly have a bad impact on the environment. Early childhood will range to imitate the behaviors seen by them. Bullying are physical, verbal, and mental / psychological affects the growth and development of children. By using qualitative methods with literature studies, the authors find the effective methode to minimize bullying to the early childhood by parenting, in the form of student's home visit, inviting the parent to the school, and case conference.

Keywords: Avoid Bullying; Early childhood; Parenting.

\section{PENDAHULUAN}

Masa anak usia dini merupakan suatu fase emas perkembangan anak. Dimana pada masa ini anak memiliki kematangan emosi, sosial, fisik dan psikis. Anak usia dini juga merupakan tahapan perkembangan yang harus dilewati dengan berbagai kesulitan.
Dalam tugas perkembangannya, anak usia dini akan melewati beberapa fase dengan berbagai tingkat kesulitan permasalahannya sehingga dengan mengetahui tugas-tugas perkembangan anak dapat mencegah konflik yang ditimbulkan oleh anak dalam keseharian yang sangat menyulitkan lingkungan, 
Astri Tirmidziani, Nur Salma Farida, Resti Fauzi Lestari, Rima Trianita, Sopi Khoerunnisa, Elfan Fanhas Fatwa Khomaeny.UPAYA MENGHINDARI BULLYING PADA ANAK USIA DINI MELALUI PARENTING. Early Childhood Vol. 2 No. 1, Mei 2018

agar tidak salah persepsi dalam menangani permasalahan tersebut.

Pada masa ini juga kondisi psikis anak sangat labil, karena masa ini merupakan fase pengenalan lingkungan. Biasanya mereka selalu ingin tahu dan mencoba sesuatu yang baru dilihat atau diketahuinya dari lingkungan sekitarnya, mulai lingkungan keluarga, sekolah, teman sepermainan dan masyarakat.

Semua pengetahuan yang baru diketahuinya baik yang bersifat positif maupun negatif akan diterima, ditanggapi kemudian ditiru oleh anak usia dini sesuai dengan kepribadian masing-masing. Karena anak usia dini adalah peniru terbaik, dan lingkungan sekitarnya adalah pelaku (role model).

Salah satu kejadian yang sering dilakukan pada anak saat bermain adalah perilaku bullying. Bullying menurut Rigby (dalam Astuti, 2008:3), sebuah hasrat untuk menyakiti. Hasrat ini diperlihatkan ke dalam aksi, menyebabkan orang menderita. Aksi ini dilakukan secara langsung oleh seseorang atau kelompok yang lebih kuat, tidak bertanggung jawab, biasanya berulang, dan dilakukan dengan perasaan senang.

Budaya bullying (kekerasan) masih terus terjadi di kalangan anak. Bullying adalah suatu bentuk kekerasan anak (child abuse) yang dilakukan teman sebaya kepada seseorang (anak) yang lebih rendah atau lebih lemah untuk mendapatkan keuntungan atau kepuasan tertentu.

\section{METODE PENELITIAN}

Metode yang digunakan dalam hal ini adalah metode deskriptif kualittatif dengan melakukan kajian literatur, dimana penulis mengkaji berbagai data dan informasi dari berbagai sumber terkait dengan topik yang dipilih. Sumber yang digunakan antara lain buku, jurnal dan sumber informasi lainnya terkait dengan Bulliying pada anak dan kegiatan parenting.

\section{HASIL DAN PEMBAHASAN Pengertian Anak Usia Dini}

Definisi anak usia dini yang dikemukan oleh NAEYC (National Assosiation Education for Young Chlidren) adalah sekelompok individu yang berada pada rentang usia antara 0 - 8 tahun. Anak usia dini merupakan sekelompok manusia yang berada dalam proses pertumbuhan dan perkembangan. Pada usia tersebut para ahli menyebutnya sebagai masa emas (Golden Age) yang hanya terjadi satu kali dalam perkembangan kehidupan manusia.

Pertumbuhan dan perkembangan anak usia dini perlu diarahkan pada fisik, kognitif, sosioemosional, bahasa, dan kreativitas yang seimbang sebagai peletak dasar yang tepat guna pembentukan pribadi yang utuh. Pengertian anak usia dini memiliki batasan usia dan pemahaman yang beragam, tergantung dari sudut pandang yang digunakan. Secara tradisional pemahaman tentang anak sering diidentifikasikan sebagai manusia dewasa mini, masih polos dan belum bisa apa-apa atau dengan kata lain belum mampu berfikir.

Pemahaman lain tentang anak usia dini adalah anak merupakan manusia kecil yang memiliki potensi yang masih harus dikembangkan. (Hurlock, 1980), masa anak usia dini dimulai setelah bayi yang penuh dengan ketergantungan, yaitu kira-kira usia 2 tahun sampai saat anak matang secara seksual. Ia memiliki karakteristik 
tertentu yang khas dan tidak sama dengan orang dewasa serta akan berkembang menjadi manusia dewasa seutuhnya.

Pandangan tentang anak beraneka ragam, ada yang menyatakan bahwa Anak adalah miniatur orang dewasa (child as miniature adult), anak sebagai pendosa (child as sinful), anak sebagai lembaran kosong (children as blank tablets), anak sebagai tanaman yang bertumbuh (children as growing plants), anak sebagai properti (children as property), dan anak sebagai investasi masa depan (children as investments) (George S Morrison : 214218), terlepas dari perbedaan pandangan tersebut, yang pasti bahwa anak terutama Anak Usia Dini (AUD) berada pada fase keemasan (the golden age) dalam pertumbuhan dan perkembangan manusia baik secara fisik, emosi, sosial, dan spiritual (Elfan, 2017 : 44)

Karaktristik anak yang unik, aktif, rasa ingin tahunya tinggi, egosentris, berjiwa petualang, daya konsentrasinya pendek, daya imajinasinya tinggi, dan senang berteman, sehingga anak dapat tumbuh dan kembang dengan baik kalau mendapatkan perlakuan kasih sayang, pengasuhan yang penuh pengertian dan dalam situasi yang damai dan harmoni dari orang sekitarnya.

Menurut Hartati (2005) anak usia dini memiliki karakteristik yang khas yaitu:

a. Anak memiliki sifat egosentris

b. Anak memiliki keingintahuan yang cukup besar

c. Anak adalah makhluk social

d. Anak bersifat unik

e. Anak memiliki imajinasi dan fantasi

f. Anak memiliki daya konsentrasi yang pendek

g. Anak paling potensial untuk belajar

Karakteristik anak tersebut di atas, menjadikan anak sangat potensial dan rentan terhadap pengaruh atau perilaku yang dari luar. Apabila pengaruh baik akan berpengaruh baik, tetapi sebaliknya apabila perilaku yang didaptkan anak tidak baik, maka akan berdampak tidak baik dan berbekas untuk jangka panjang.

\section{Pengertian dan Bentuk-Bentuk Bullying}

Bullying dari kata bully yang artinya menggertak, orang yang menganggu orang yang lemah. bullying adalah penyalahgunaan kekuasaan yang berkelanjutan dalam suatu hubungan, melalui tindakan verbal, fisik, dan sosial yang berulang, yang menyebabkan kerugian fisik dan psikologis.

Tindakan ini dapat dilibatkan ini dapat melibatkan individu atau kelompok menyalahgunakan kekuasaan mereka pada satu atau lebih orang lain. Bulliying dapat terjadi secara langsung atau ranah maya, dan dapat tampak jelas atau tersembunyi. Kejadian tunggal dan konflik atau perkelahian antara pihak yang setara, entah secara langsung atau di ranah maya tidak didefinisikan sebagai bullying.

Rigby (2005; dalam Anesty, 2009) merumuskan bahwa "bullying" merupakan hasrat untuk menyakiti. Hasrat ini diperlihatkan dalam aksi,menyebabkan orang lain menderita. Aksi ini dilakukan secara langsung oleh seseorang atau sekelompok orang yang lebih kuat, tidak bertanggung jawab, biasanya berulang dan dilakukan dengan perasaan senang.

Olweus (1993; dalam Anesty, 2009) memaparkan contoh tindakan negatif yang termasuk dalam bullying antara lain;

a. Mengatakan hal yang tidak menyenangkan atau memanggil seseorang dengan julukan yang buruk. 
b. Mengabaikan atau mengucilkan seseorang dari suatu kelompok karena suatu tujuan.

c. Memukul, menendang, menjegal atau menyakiti orang lain secara fisik.

d. Mengatakan kebohongan atau rumor yang keliru mengenai seseorang atau membuat siswa lain tidak menyukai seseorang dari halhal semacamnya.

Berdasarkan penjelasan di atas, jadi dapat disimpulkan bahwa bullying adalah hasrat untuk menyakiti, menyebabkan orang lain menderita, dilakukan secara langsung oleh seseorang atau sekelompok orang yang lebih kuat, dan tidak bertanggung jawab, biasanya berulang dan dilakukan dengan perasaan senang.

1. Faktor-faktor bullying

$$
\text { Banyak faktor-faktor }
$$

penyebab terjadinya perilaku bullying. Qurroz dkk (2006; dalam Anesty, 2009) mengemukakan sedikitnya terdapat tiga faktor yang dapat menyebabkan perilaku bullying sebagai berikut.

a. Hubungan keluarga.

Anak akan meniru berbagai nilai dan perilaku anggota keluarga yang ia lihat sehari-hari sehingga menjadi nilai dan perilaku yang ia anut (hasil dari imitasi). Sehubungan dengan perilaku imitasi anak, jika anak dibesarkan dalam keluarga yang menoleransi kekerasan atau bullying, maka ia mempelajari bahwa bullying adalah suatu perilaku yang bisa diterima dalam membina suatu hubungan atau dalam mencapai apa yang di lingkunganya (image), sehingga kemudian ia meniru (imitasi) perilaku bullying tersebut.

b. Teman sebaya.

Salah satu faktor besar dari perilaku bullying pada remaja disebabkan oleh adanya teman sebaya yang memberikan pengaruh negatif dengan cara menyebarkan ide (baik secara aktif maupun pasif) bahwa bullying bukanlah suatu masalah besar dan merupakan suatu hal yang wajar untuk dilakukan.

c. faktor Sekolah

Menurut Setiawati (seperti dikutip dari Usman), kecenderungan pihak sekolah yang sering mengabaikan keberadaan bullying menjadikan siswa yang menjadi pelaku bullying semakin mendapatkan penguatan terhadap perilaku tersebut. Selain itu, bullying dapat terjadi di sekolah jika pengawasan dan bimbingan etika dari para guru rendah ,sekolah dengan kedisiplinan yang sangat kaku,bimbingan yang tidak layak dan peraturan yang tidak konsisten.

d. Media Massa

Saripah mengutip sebuah survey yang dilakukan Kompas (seperti yang dikutip dari Masdin) yang memperlihatkan bahwa 56,9\% anak meniru adegan-adegan film yang ditontonnya, umunya mereka meniru gerakannya $(64 \%)$ dan kata-katanya (43\%).Hal ini dapat menciptakan perilaku anak yang keras dan kasar yang selanjutnya memicu terjadi bullying yang dilakukan 
oleh anak-anak terhadap teman-temannya di sekolah.

e. Faktor Budaya

Faktor kriminal budaya menjadi salah satu penyebab munculnya perilaku bullying. Suasana politik yang kacau, perekonomian yang tidak menentu, prasangka dan diskriminasi, konflik dalam masyarakat, dan ethnosentrimehalini dapat mendorong anak-anak dan remajamenjadi seorang yang depresi, stress, arogan dan kasar.

2. Bentuk-bentuk bullying

Bentuk bullying menurut Coloroso (2007:47) dibagi menjadi empat jenis, sebagai berikut:

a. Bullying fisik seperti memukul, mendorong, mencekik, menggigit, menampar, menendang, meninju, mengunci seseorang dalam ruangan, mencubit, mencakar, menodongkan senjata, menginjak kaki, melempar dengan barang, meludahi, menghukum dengan cara pushup, menarik baju, menjewer, menyenggol, menghukum dengan cara membersihkan WC, memeras dan merusak barang orang lain.

b. Bullying verbal seperti memberikan julukan nama, celaan, fitnah, penghinaan, menuduh, menyoraki, memaki, mengolok-olok, serta menebar gosip.

c. Bullying mental/psikologis seperti memandang dengan sinis, menjulurkan lidah, menampilkan ekspresi wajah yang merendahkan, mengejek, memandangdengan penuh ancaman, mempermalukan di depan umum, mengucilkan, memandang dengan hina, mengisolir, menjauhkan, dan lain- lain.

\section{Parenting sebagai Solusi Mengatasi Bullying}

Saat ini, bullying menjadi permasalahan yang terjadi disekitar Anak, Hal ini tentunya akan memberikan dampak yang negatif terhadap pertumbuhan dan perkembangan anak, baik anak menjadi korban ataupun pelaku tindakan bullying. Dampak tersebut akan muncul secara langsung atau dikemudian hari.

Upaya menghentikan tindakan bullying harus dilakukan oleh seluruh pihak, baik guru, orang tua, masyarakat, dan negara. Dampak terberat dari bullying adalah dampak jangka panjang dan turun temurun, sehingga manusia menjadi liar dan hilang rasa kasih sayangnya.

Orang tua adalah benteng pertama dan utama dalam meminimalisir prilaku bullying pada anak, sehingga peran orang tua dalam menangkal perilaku bullying pada anak sangat besar, tetapi fakta dilapangan banyak orang tua yang tidak memiliki pengetahuan tentang prilaku bullying dan dampak yang akan terjadi, sehingga ketika anaknya menjadi pelaku atau korban bullying menganggap hal yang biasa terjadi pada anak, yang tidak perlu dikhawatirkan. Usaha sekolah membangun hubungan dan memberikan pemahamann tentang program sekolah dan tumbuh kembang anak, adalah keniscayaan yang harus dilakukan untukdapat berhasil mendidik anak.

Parenting adalah cara orang tua bertindak sebagai orangtua terhadap anak-anaknya dimana mereka melakukan serangkaian usaha aktif, 
karena keluarga merupakan lingkungan kehidupan yang dikenal anak untuk pertama kalinya dan untuk seterusnya anak belajar didalam kehidupan keluarga (Gunarsa, 1995:141). Parenting berfungsi untuk membangun komunikasi dan kerjasama antara pihak sekolah dengan orang tua, dengan cara memberikan pengetahuan dan wawasan tentang anak dan program pendidikan anak yang harus dilakukan oleh orang tua bersama sekolah. Ada berbagai istilah yang digunakan untuk menyebut pendidikan orangtua, seperti school parenting, parenting club dan parenting school. Minimnya sekolah yang menerapkan parenting education karena dalam penerapannya kegiatan ini membutuhkan waktu, sarana dan prasarana yang memadai.

$$
\text { Di dalam UU Nomor } 2 \text { Tahun }
$$

1989 tentang Sistem Pendidikan Nasional Pasal 10 ayat (4). Dinyatakan bahwa : pendidikan keluarga merupakan bagian dari jalur pendidikan luar sekolah yang diselenggarakan dalam keluarga dan yang memberikan keyakinan agama, nilai budaya, nilai moral, dan keterampilan.

\section{Bentuk Kegiatan Parenting}

Untuk menghindari perilaku bullying yang dilakukan oleh anak, orang tua harus mengerti bahwa perbuatan bullying tidak baik bagi tumbuh kembang anak. Orang tua harus mengerti tentang bahaya dan cara menghindari perilaku bullying pada anak, maka diperlukan adanya kegiatan parenting. Keterlibatan orang tua ini perlu di dorong karena dapat membantu guru membangun harga diri guru di hadapan anak didik dalam menanamkan kedisiplinan dan mengurangi problem kehidupan serta meningkatkan kesadaran untuk belajar. Kegiatan parenting yang bisa dilakukan seperti :

1. Adanya kunjungan ke Rumah Anak Didik

Pelaksanaan kunjungan ke rumah anak didik ini berdampak sangat positif, diantaranya :

1) Melahirkan perasaan pada anak didik bahwa sekolahnya selalu memerhatikan dan mengawasinya.

2) Memberikan kesempatan kepada pendidik untuk melihat dan mengobservasi langsung cara anak didik belajar, latar belakang hidupnya, dan tentang masalah-masalah yang dihadapinya.

3) Pendidik berkesempatan untuk memberikan penerangan kepada orangtua anak didik tentang pendidikan yang baik, cara-cara menghadapi masalah-masalah yang sedang dialami anaknya, dan sebagainya.

4) Hubungan antara orang tua dengan sekolah akan bertambah erat.

5) Memberikan motivasi kepada orang tua untuk lebih terbuka dan dapat bekerja sama dalam upaya memajukan pendidikan anaknya.

6) Pendidik berkesempatan untuk mengadakan interview mengenai berbagai macam keadaan atau kejadian tentang sesuatu yang ingin ia ketahui.

7) Terjadinya komunikasi dan saling memberikan informasi tentang keadaan anak serta saling memberi petunjuk antar guru dengan orang tua. 
Kunjunga pihak sekolah ke guru dilakukan dalam rangka mengkomunikasikan tentang capaian pertumbuhan dan perkembangan anak selama ada di sekolah, sambil mencoba menggali informasi kehidupan anak selama berada di bawah pengawan orang tua di rumah, sehingga dari informasi yang didapatkan dari orang tua pihak sekolah bisa bekerjasama dan mengambil tindakan untuk perbaikan kegiatan bagi anak.

2. Diundangnya Orang Tua ke Sekolah

Kalau ada berbagai kegiatan yang dilaksanakan oleh sekolah yang memungkinkan untuk dihadiri oleh orang tua, maka akan memberikan dampak yang positif. Seperti diundangnya orang tua dalam acara class meeting yang berisi perlombaan-perlombaan yang mendemonstrasikan kebolehan anak dalam berbagai bidang.

Sekolah harus mengagendakan pertemuan rutin sekaligus memberikan pengetahuan dan wawasan tentang tumbuh kembang anak melalui pakar yang di datangkan pihak sekolah, sehingga orang tua memiliki kesamaan pemahaman dengan guru dalam mendidik anaknya

\section{Case Conference}

Case Conference merupakan rapat atau konferensi tentang kasus. Hal ini dilakukan oleh sekolah ketika menemukan kejanggalan atau ketidaknormalan prilaku anak, sehingga perlu adanya penanganan secara khusus oleh pihak sekolah, dengan melibatkan peran orang tua dalam mencari solusinya.

Parenting dalam berbagai bentuknya, apakah melakukan kunjungan, mengundang orang tua ke sekolah dan case conference dapat dijadikan salah satu cara untuk memberikan pemahaman kepada orang tua tentang bullying dan dampak yang akan terjadi. Dengan adanya pemahaman yang baik dan benar dari orang tua tentang bullying, maka orang tua dapat mendeteksi dini dan berperan aktif dalam meminimalisir perilaku bullying, baik sebagai pelaku maupun korban.

\section{SIMPULAN}

Upaya menghindari bullying pada anak usia dini adalah melalui kegiatan parenting, yaitu upaya memberikan pemahaman kepada orang tua tentang perbuatan bullying dan bahayanya bagi tumbuh kembang anak, serta memiliki pemahaman dan kemampuan untuk menghindari perilaku bullying pada anak. Parenting dapat dilakukan dengan berbagai macam cara, diantaranya : kunjungan ke rumah anak didik, mengundang orang tua ke sekolah, dan case conference. 
Astri Tirmidziani, Nur Salma Farida, Resti Fauzi Lestari, Rima Trianita, Sopi Khoerunnisa, Elfan Fanhas Fatwa Khomaeny.UPAYA MENGHINDARI BULLYING PADA ANAK USIA DINI MELALUI PARENTING. Early Childhood Vol. 2 No. 1, Mei 2018

\section{DAFTAR PUSTAKA}

Esya, Anesty. (2009). Konseling Kelompok Behavioral Untuk Mereduksi Perilaku Bullying Siswa Sekolah Menengah Atas (Penelitian Eksperimen Kuasi terhadap Siswa Kelas XI Sekolah Menengah Atas Negeri 10 Bandung). Skripsi di Jurusan Psikologi Pendidikan dan Bimbingan UPI Bandung: Tidak diterbitkan

Coloroso, B. 2007. Stop Bullying. Jakarta : Serambi Ilmu Smesta

Dewi Arum WMP. 2016. Pembimbingan Anak Usia Dini Pada Taman KanakKanak di Kota Singaraja. Vol. 5. Hal. 30-32

Elfan Fanhas F Kh, Gina Nurazizah Mukhlis. Pendidikan Karaktek Untuk Anak Usia Dini Menurut Q.S. Lukman : 13-19. PEDAGOGI: Jurnal Anak Usia Dini dan Pendidikan Anak Usia Dini Volume 3 Nomor 3a

Desember 2017 Hal. 42-51

Elizabeth B Hurlock. 1980. Psikologi Perkembangan: Suatu Pendekatan Sepanjang Rentang Kehidupan. Jakarta : Gramedia.

George S Morrison (2016). Pendidikan Anak Usia Dini Saat Ini Edisi 13 (penerj Yudi Santoso). Yogyakarta : Pustaka Pelajar

Gunarsa. 1995. Psikologi Perkembangan Anak Remaja. Jakarta : Gunung Mulia

Hasbullah. 2017. Dasar-Dasar Ilmu Pendidikan. Depok : Rajawali Pers.
Ilga Maria, Ria Novianti. 2017. Pengaruh pola asuh dan bullying terhadap harga diri (self esteem) Pada anak kelompok $b$ tk di kota pekanbaru. Vol. 6

Muliani Hanlie dan Robert Pereira. 2018. Why Children Bully?. Jakarta : PT Grasindo

Meriyati. 2016. Membangun Karakter Anak Sejak Usia Dini. Vol. 1

Nur Tanfidiyah. 2017. Perkembangan Agama dan Moral yang Tidak Tercapai Pada AUD. Vol. 11. Hal. 200

Suyadi dan Maulidya Ulfah. 2015. Konsep Dasar PAUD. Bandung : PT. Remaja Rosdakarya

Siti Nur Muanah. 2016. Parenting Education Sebagai Pendidikan Keluarga. Vol. 4

Tridhonanto. 2014. Mengapa Anak Mogok Sekolah?, Vol. 1. Hal 70

Windy Sartika Lestari. 2016. Analisis Faktor-Faktor Penyebab Bulyying di Kalangan Peserta Didik. Vol. 3. Hal 148 